\title{
Typification of seven species of Encyonema and characterization of Encyonema leibleinii comb. nov.
}

\author{
Weliton José SiLvA ${ }^{1, *}$, Regine JAHN², Thelma Alvim Veiga Ludwig ${ }^{3}$ \& Mariângela \\ MENEZES $^{1}$
}

\author{
${ }^{1}$ Labfico, Departamento de Botânica, Museu Nacional, Universidade Federal do Rio de Janeiro, RJ, Brazil; *Corresponding \\ authore-mail: welitondasilva@yahoo.com.br \\ ${ }^{2}$ Botanischer Garten und Botanisches Museum Berlin-Dahlem, Freie Universität, Berlin, Germany \\ ${ }_{3}^{3}$ Departamento de Botânica, Setor de Ciências Biológicas, Universidade Federal do Paraná, Centro Politécnico, Curitiba, \\ PR, Brazil
}

\begin{abstract}
The first species described in the genus Encyonema were not lectotypified. Despite the absence of types, some specialists have either defended or accepted synonymizations based on their own concepts, such as in the cases of Encyonema prostratum, Gloionema paradoxum, G. leibleinii and E. paradoxum, the type of the genus Encyonema. We aimed to lectotypify E. paradoxum, E. prostratum, E. cespitosum, E. triangulum, Gloionema paradoxum, G. leibleinii and E. lacustre. Original material was inspected and characterized. These lectotypifications resulted in the verification of the conspecificity of $E$. paradoxum, E. prostratum and G. leibleinii, and in the designation of E. leibleinii comb. nov.
\end{abstract}

Key words: Encyonema paradoxum, Gloionema, Gloionema paradoxum, Cymbellales, diatoms, lectotype, epitype

\section{INTRODUCTION}

In the taxonomy of any organism, the application of names is based on nomenclatural types (LAPAGE et al. 1992; Ride et al. 1999; McNeILL et al. 2012). This principle ensures the identity of taxa below the family level and links them to only one specimen. However, the indication of a type became a requirement in botany only after 1958 (MCNeILl et al. 2012). Thus, many taxa published before that date lacked a type indication. This is the case for the genus Encyonema KüTz. and many of its species.

KüTZING (1833) published the new monospecific genus Encyonema, which was characterized as a gelatinous-membranaceous filament, thin, hyaline, single and continuous, within which cymbelloid organisms are longitudinally organized. At that time, the only species described was Encyonema paradoxum KüTZING, which must automatically be considered the type species of the genus. However, the type specimen of E. paradoxum is still undefined. EHRENBERG (1838) considered E. paradoxum and Gloionema leibleinii C. Agardh, which to this date have not been characterized, as synonyms of Gloionema paradoxum C. AgARDH, another species that is not yet typified. This synonymization was based mainly on the characteristics of the colony.

In 1844, KüTZING again cited E. paradoxum, providing more details of this species and showing specimens with more acute apices and a slight intumescence on the midventral part of the frustules. KüTZING (1844) also described the second species in this genus, E. prostratum (BеRк.) Kütz., which was a new combination for Monema prostratum BeRK. Nevertheless, these two species became confused, because KüTZING (1849) concluded that $E$. paradoxum sensu KüTZING (1844) agrees with $M$. prostratum. He also determined that E. prostratum sensu KüTZING (1844) was different from Monema prostratum, and therefore described it as a new species, E. cespitosum KüTZ. Further, KüTZING (1849) transferred Gloionema triangulum EHRENB. and Gloionema sigmoides EHRENB. to Encyonema, resulting in the new combinations E. triangulum (EHRENB.) KüTz. and E. sigmoides (EhrenB.) KüTZ., respectively.

Subsequently, RABENHORST (1853) published the taxon E. auerswaldii RABENH., which is very similar to E. prostratum and E. cespitosum. Because of this similarity, he revisited the concepts of E. paradoxum, E. prostratum and E. cespitosum, basing his decisions only on the original drawings and descriptions of these taxa. RABENHORST's (1853) was the last study that cited E. paradoxum.

Patrick \& Reimer (1975) considered Encyonema to be a synonym of the genus Cymbella, according to the concepts of Heiberg (1863). Moreover, they treated E. cespitosum pro part., E. auerswaldii and E. cespitosum [caespitosum] var. auerswladii (Küтz.) VAN HEURCK as a variety of $C$. prostrata, resulting in the new combination $C$. prostrata var. auerswaldii 
(RABENH.) ReImer. However, this synonymization was not accompanied by a study of the types of $E$. prostratum or E. cespitosum, but was based only on the concepts developed to that date, mainly those of VAN Heurck (1885).

The original specimens of E. paradoxum, $E$. prostratum and $E$. cespitosum were lost. In the case of E. cespitosum, KRAMMER (1997a) designated a neotype. However, the International Code of Nomenclature for algae, fungi and plants (ICN) established that a neotype can only be designated when all original materials are lost (McNeILL et al. 2012). In Article 9.3, the ICN also states that the original material comprises specimens and illustrations (published or not). Thus, the designation of a neotype of $E$. cespitosum by KRAMMER (1997a) does not concord with the ICN rules, and we can consider that E. paradoxum, E. prostratum and E. cespitosum were still not typified. Similarly, other species that were originally described in other genera but are today considered to belong to Encyonema (e.g., Gloionema triangulum EHRENB. and Schizonema lacustre C. AGARDH) also were not typified.

In this contribution, we lectotypify $E$. paradoxum, E. prostratum, E. cespitosum, E. triangulum, Gloionema paradoxum, G. leibleinii and E. lacustre (C. Agardh) PANT. We also verify the conspecificity of E. paradoxum, E. prostratum and $G$. leibleinii and propose the new combination E. leibleinii.

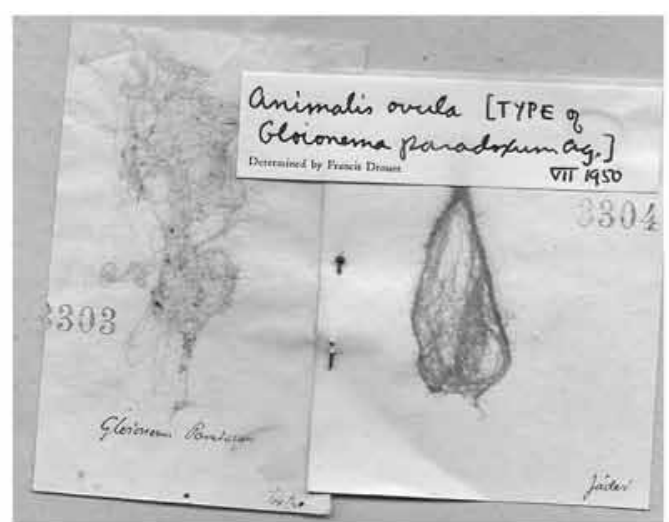

1
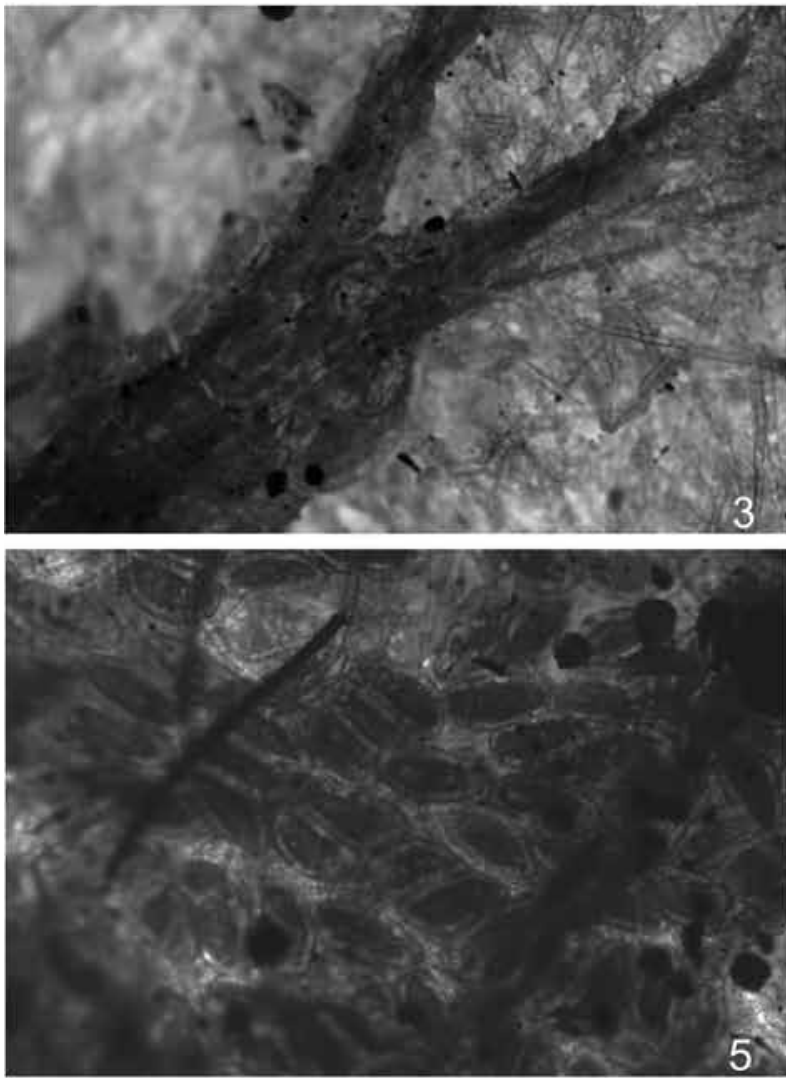
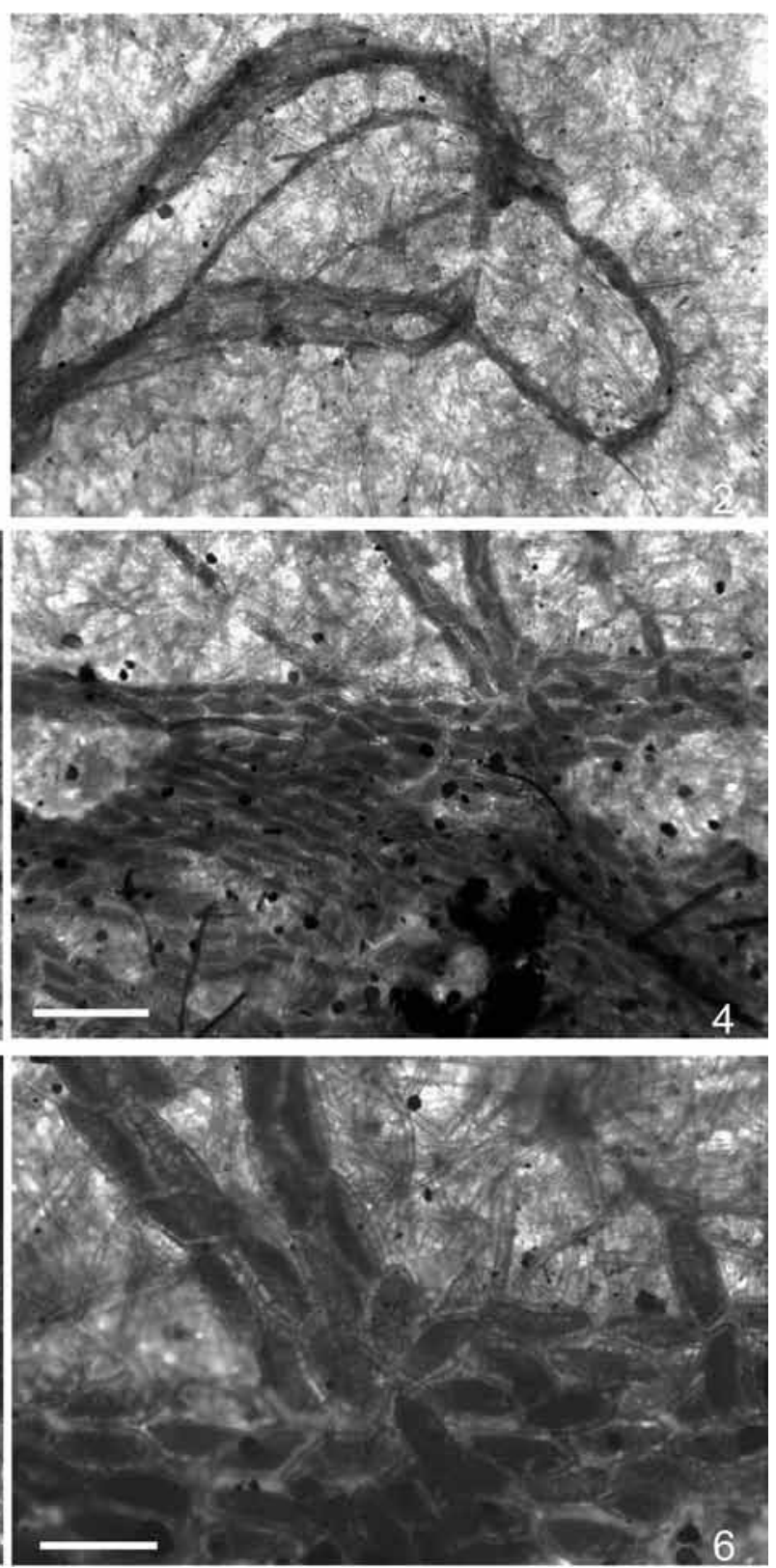

Figs 1-6. Type element of Gloionema paradoxum C.Agardh [LD 3303, LD 3304]: (1) Exsiccate LD 3303 and 3304; (2-6) Gloionema paradoxum C.Agardh, viewed on paper. Scale bars (Figs 2-4) $500 \mu \mathrm{m}$; (Figs 5-6) $200 \mu \mathrm{m}$. 


\section{Materials And Methods}

The term "original material" is used here according to the ICN (MCNeILL et al. 2012). The following materials were analyzed:

Encyonema cespitosum. Preparation 321 IOK from "Weissensee b. Füssen" in the Alfred-Wegener-Institut für Polar- und Meeresforschung (BRM), Bremerhaven [designated by KramMER (1997a, p. 118) as the neotype];

Encyonema auerswaldii. Preparations 1126 and 1127 IOK ex RABENHORST No. 1385 in the Alfred-Wegener-Institut für Polar- und Meeresforschung (BRM), Bremerhaven [isotype];

Encyonema prostratum. Preparation 321 IOK. in the AlfredWegener-Institut für Polar- und Meeresforschung (BRM), Bremerhaven.

Encyonema prostratum. Preparation B 400040926 from a periphyton sample collected in a small boat park, Tegel Lake (52॰35'20.83“N; 13¹6“19.65“E), legatee W. SiLVA, 11.7.2011, in the Botanischer Garten und Botanisches Museum Berlin-Dahlem, Zentraleinrichtung der Freien Universität Berlin (B), Germany.

Gloionema [Gloeonema] triangulum (三E. triangulum). Preparation no. 250608c "Niagara", marked with a lilac ring, in the Ehrenberg Collection in the Museum für Naturkunde (BHUPM), and the drawing sheet No. 2079 (http://download.naturkundemuseum-berlin.de/ Ehrenberg/Ec\%20Drawings/Ec\%20draw\%2020002999/Ec\%20draw\%202000-2099/ec\%20dr\%202079. jpg) [vide LAZARUS \& JAHN (1998) on the correct use of the Ehrenberg Collection];

Gloionema paradoxum. Exsiccates 3303 and 3304 in the Herbarium of the University of Lund (LD), Sweden.

Gloionema leibleinii [leibleini]. Exsiccate 3299 in the Herbarium of the University of Lund (LD), Sweden.

Gloionema [Gloeonema] paradoxum sensu EHRENBerg (1838). Preparations 250603e "Niagara", marked with a blue ring (bl), Museum für Naturkunde (BHUPM); 250604c "Niagara", marked with a white ring (w) (BHUPM); and the drawing sheet No. 677 (http:// download.naturkundemuseum-berlin.de/Ehrenberg/ Ec\%20Drawings/Ec\%20draw\%20001-999/Ec\%20 draw\%20600-699/ECdraw677.jpg).

Schizonema lacustre. Exsiccate 3673 in the Herbarium of the University of Lund (LD), Sweden.

Herbariums where parts of the Kützing Collection [e.g., Natural History Museum (BM), Botanischer Garten und Botanisches Museum (B), etc.] and the Berkeley Collection are held were contacted in order to find the original material of E. paradoxum, M. prostratum and E. cespistosum.

Small probes of the material of exsiccates 3299 (G. leibleinii) and 3673 (S. lacustre) were carefully scraped and oxidized using hydrogen peroxide in order to obtain permanent slides. Two slides were made from each exsiccate; one of each pair received the same number as the exsiccate and was deposited in $\mathrm{LD}$, and the others, of the isolectotypes of S. lacuste and G. leibleinii, were deposited in the Herbarium of the Museu Nacional (R), Brazil, under numbers R 214.004 and R 214.005, respectively.

The materials from BRM were analyzed with the aid of a Zeiss Axio Imager 4.2 microscope $(1000 \times)$ and photographed with an Axiocam MRc/MRm capture system with software AxioVision Rel. 4.8. The materials from
BHUPM were analyzed with an Olympus BX 51 microscope $(400 \times)$ and photographed with an Olympus DP 50 digital camera [vide detailed characterization in JAHN \& KUSBER (2006)]. The materials from LD and R were analyzed under an Olympus BX 51, equipped with a CoolSNAP-Procf digital camera (MediaCybernetics) coupled to the $\mathrm{Q}$ capture Pro QImaging( software (Olympus).

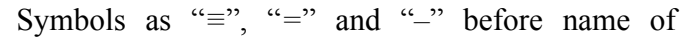
specific and infraspecific were used to represent homotypic or nomenclatural, heterotypic or taxonomical, and concept synonyms, respectively, as used in the ICN (MCNeILl et al. 2012).

\section{Results}

\section{Gloionema C. Agardh}

Type of the genus name: Gloionema paradoxum $\mathrm{C}$. Agardh.

Original description: "Fila gelatinosa tenacia continua. Sporangia? elliptica sparsa”.

Gloionema paradoxum C. AgardH, 1812, Dispositio Algarum Sueciae 5: 45 (figs 45-50) [non Gloionema paradoxum C. Agardh sensu Ehrenberg (1838, p. 237) (figs 51-55)].

Original description: See the generic description [considered as a descriptio generico-specifica according to Article 38.5 of McNeILL et al. (2012)].

Lectotype (here designated): Exsiccate 3303 in the Herbarium of the University of Lund (LD), Sweden (figs 45-50).

Type locality: "In Mälaren, \& in fluvio ad Jäder Westmaniae fluctuans".

Remarks: The lectotype of $G$. paradoxum, type of the genus Gloionema, proved not to be a diatom. Macroscopically, G. paradoxum showed an arrangement of branched pseudofilaments (Fig. 1). Microscopically, the pseudofilaments were composed by aggregated cells organized serially and covered by mucilaginous substances (Figs 2, 3). Some of these pseudofilaments were branched. The material surrounding the cells was not fused. They showed irregular outlines and seemed to be whole. The layer lacked any structure (Figs 4-6). The cells were $180-215 \mu \mathrm{m}$ in length and $67-87 \mu \mathrm{m}$ in breadth.

\section{Encyonema KüTz.}

Type of the genus name: Encyonema paradoxum KüTZING.

Original description: "fila felatinoso-membranacea, terrima, hyaline, simplicia, continua, libera, intus cymbellas longitudilatiler simplici serie dispositas continentia".

Encyonema leibleinii (C. Agardh), comb. nov. (Figs 7-17).

Basionym: Gloionema leibleinii C. Agardh, 1830, 
Consp. Crit. Diatom.: 31 .

Lectotype (here designated): One marked specimen in preparation LD 3299 made from material of exsiccate 3299, in the Herbarium of the University of Lund (LD), Sweden (Fig. 14).

Isolectotype: Marked specimen on slide R 214.005, in the Herbarium of the Museu Nacional (R), produced from oxidized material of the exsiccate 3299 (LD).

Type locality: "In aquis circa Wirceburgum".

Original description: "filis abbreviatis, granulis uniseriatis fuscis".

Remarks: Specimens within a mucilaginous tube, varying in breadth from 23.3 to $32.51 \mu \mathrm{m}$. Valvae dorsiventral, semi-lanceolate to slightly lanceolate, dorsal margin strongly convex, ventral margin straight to slightly convex, sometimes showing an intumescence in the middle part of the ventral margin, ventral side wide; rounded ends slightly displaced to the ventral side; length: 43.4-55.43 $\mu \mathrm{m}$, breadth: 17.5 $20.8 \mu \mathrm{m}$, length/breadth ratio: 2.48-2.89; axial area straight and filiform, central area distinct, rounded; raphe lateral, terminal ends deflected to the ventral side, proximal ends slightly deflected to the dorsal side, terminal nodules positioned on the ventral side, central nodule on the dorsal side; striae radiate on the dorsal side, sometimes becoming convergent, striae radiate on the ventral side, becoming convergent close to the ends, commonly one short stria in the middle part of the ventral side, the arrangement of the striae conforms to the outline of the ends, $6-12$ striae in $10 \mu \mathrm{m} ; 16-21$ puncta in $10 \mu \mathrm{m}$; stigmata absent.

Synonyms: Monema prostratum Berk., 1832, Glean. Brit. Alg.: 15, pl. 4, fig. 3; = Encyonema prostratum (BERK.) KüTZ., 1844, Bacill. 82; $\equiv$ Schizonema prostratum (BERK.) Grev. in HoOKER, 1833, Brit. Fl. 2(1): 414; 三 Encyonema prostratum (BERK.) KüTZ., 1844, Bacill.: 82; - Encyonema paradoxum Kütz. sensu KüTzING (1844); - Gloionema paradoxum C. AgARDH sensu EHRENBERG (1838) (figs 51-55) non Gloionema paradoxum C. AGARDH (figs 18-29).

Lectotype (here designated): One figure in BERKELEY (1832, tab. 4, fig 3) (Fig. 14).

Type locality: England.

Epitype (here designated): One specimen in preparation B 400040926 at the Botanischer Garten und Botanisches Museum Berlin-Dahlem (B) (Fig. 22).

Type locality (epitype): Periphyton sample collected in a small boat park, Tegel Lake $\left(52^{\circ} 35^{\prime} 20.83^{\prime}\right.$ N; $\left.13^{\circ} 16^{\prime} 19.65^{\prime} \mathrm{E}\right)$, Berlin, legatee W. Silva, 11.7.2011, in the Botanischer Garten und Botanisches Museum Berlin-Dahlem, Zentraleinrichtung der Freien Universität Berlin (B), Germany.

Original description: "Threads brown, procumbent, simple, flexuous, obtuse, containing a single row of granules, which are either simple, subelliptic, with one margin more curved; or cylindrical, with obtuse ends; or double of two cylindrical portions".

= Encyonema paradoxum KüTz., 1833, Linnaea 8(5):
589, pl. VII, fig. 73 (Figs 30-31).

Lectotype (here designated): One figure in KüTZING (1833, pl. VII, fig. 73) (Fig. 31).

Type locality: "Merseberg" [Merseburg], Germany. Original description: "Filo adnato, flexuoso, frutulis cymbiformibus hyalinis, obtusis, fasciis binis transversalibus lutescentibus".

Encyonema cespitosum KüTz., 1849, Sp. Alg.: 61. (Figs 32-41).

Lectotype (here designated): One figure on plate 25 , fig. VII in KüTZING (1844) (Fig. 33).

Type locality: “An Wassermühlen in Jütland”, Jutland. Epitype (here designated): One specimen from preparation 321 IOK, at BRM, Bremerhaven (Fig. 34). Type locality (epitype): Weissensee, Füssen, Germany. Original description: " $E$. stratum gelatinosum formans, tubulis maxime intricatis, cymbellis latioribus obtusiusculis non cornutis, striates. - Long. cymbellarum 1/130-1/120".."

Remarks: Valvae dorsiventral, slightly lanceolate, dorsal margin strongly convex, ventral margin straight to slightly convex, sometimes showing an intumescence in the middle part of the ventral margin; rounded ends not protracted to slightly displaced to the ventral side; length: $21.7-44 \mu \mathrm{m}$, breadth: $9.6-12$ $\mu \mathrm{m}$, length/breadth ratio: 2.04-4.1; axial area straight and linear-lanceolate, central area indistinct to slightly rounded; raphe lateral, terminal ends deflected to the ventral side, proximal ends slightly deflected to the dorsal side, terminal nodules lying on the ventral side, central nodule on the dorsal side; striae radiate on the dorsal side, striae radiate on the ventral side, becoming convergent close to the ends, striae on the ventral margin of the same size, rarely one different, $8-11$ striae in $10 \mu \mathrm{m} ; 15-20$ puncta in $10 \mu \mathrm{m}$; stigmata absent.

Synonym: - Encyonema prostratum (BERK.) KüTz. sensu KÜTZING (1844).

Encyonema auerswaldii RABENH., 1853, Süss.Diat.: 24, pl. VII, fig. 2. (Figs 42-45).

Lectotype: A-G.C. 11402, ex RABENH. N. 1385, at Botanical Museum (LD), Lund, Sweden, designated by Reimer in PAtrick \& ReIMER (1975, p. 41).

Isolectotype: Preparations 1126 and 1127 IOK at Alfred-Wegener-Institut für Polar- und Meeresforschung (BRM), Bremerhaven (Figs 42-45).

Type locality: Leipzig.

Remarks: Valvae dorsiventral, slightly lanceolate,

Figs 7-17. Encyonema leibleinii (C. AgARDH) comb. nov [三 Gloionema leibleinii C.AgARDH]: (7) Exsiccate Ag. 3299 in LD, Sweden; $(8,9)$ Specimens in mucilaginous tube, material on paper; (10-17) Oxidized material, (14) Lectotype (here designated). Scale bar $10 \mu \mathrm{m}$. 

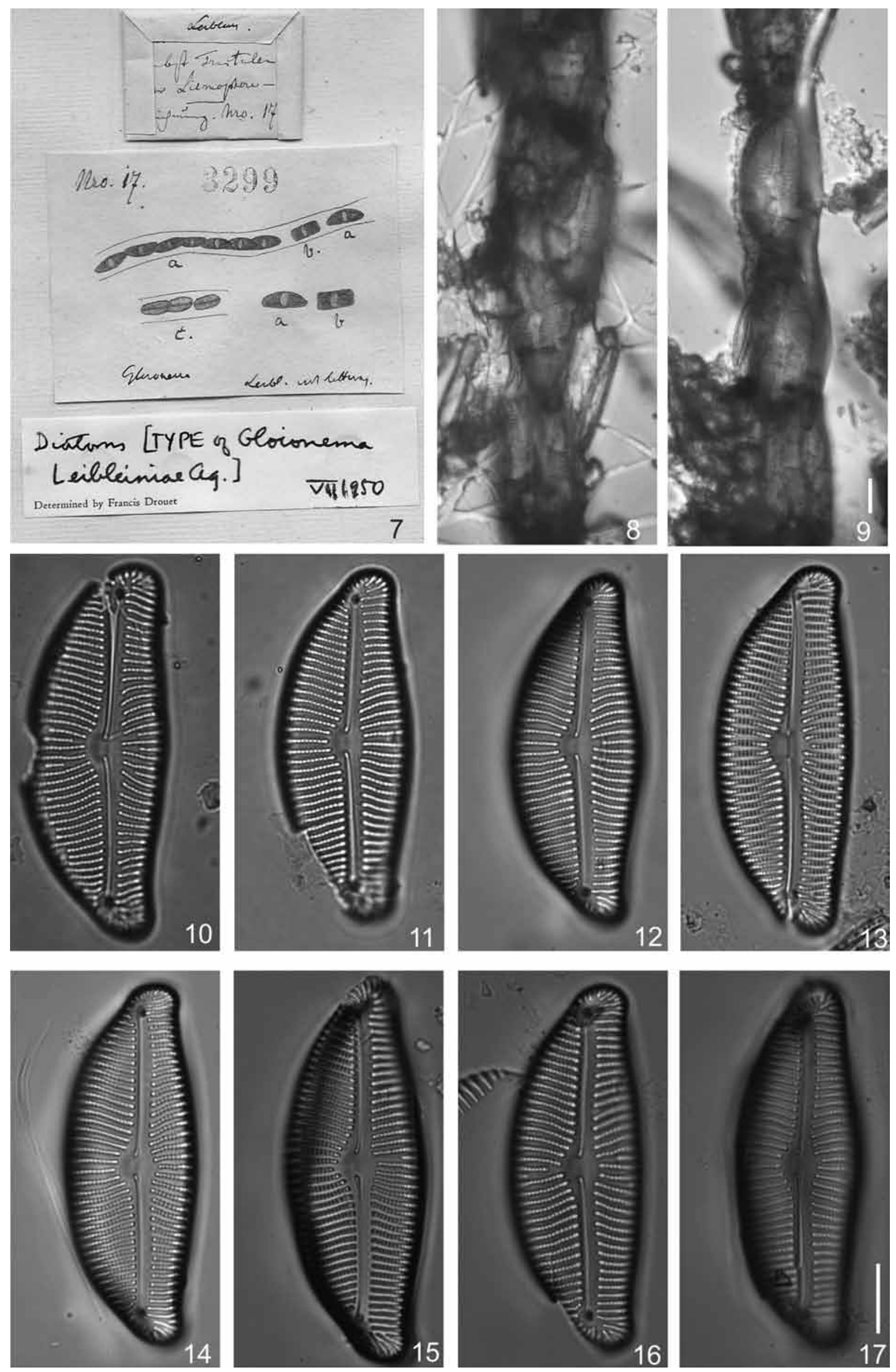


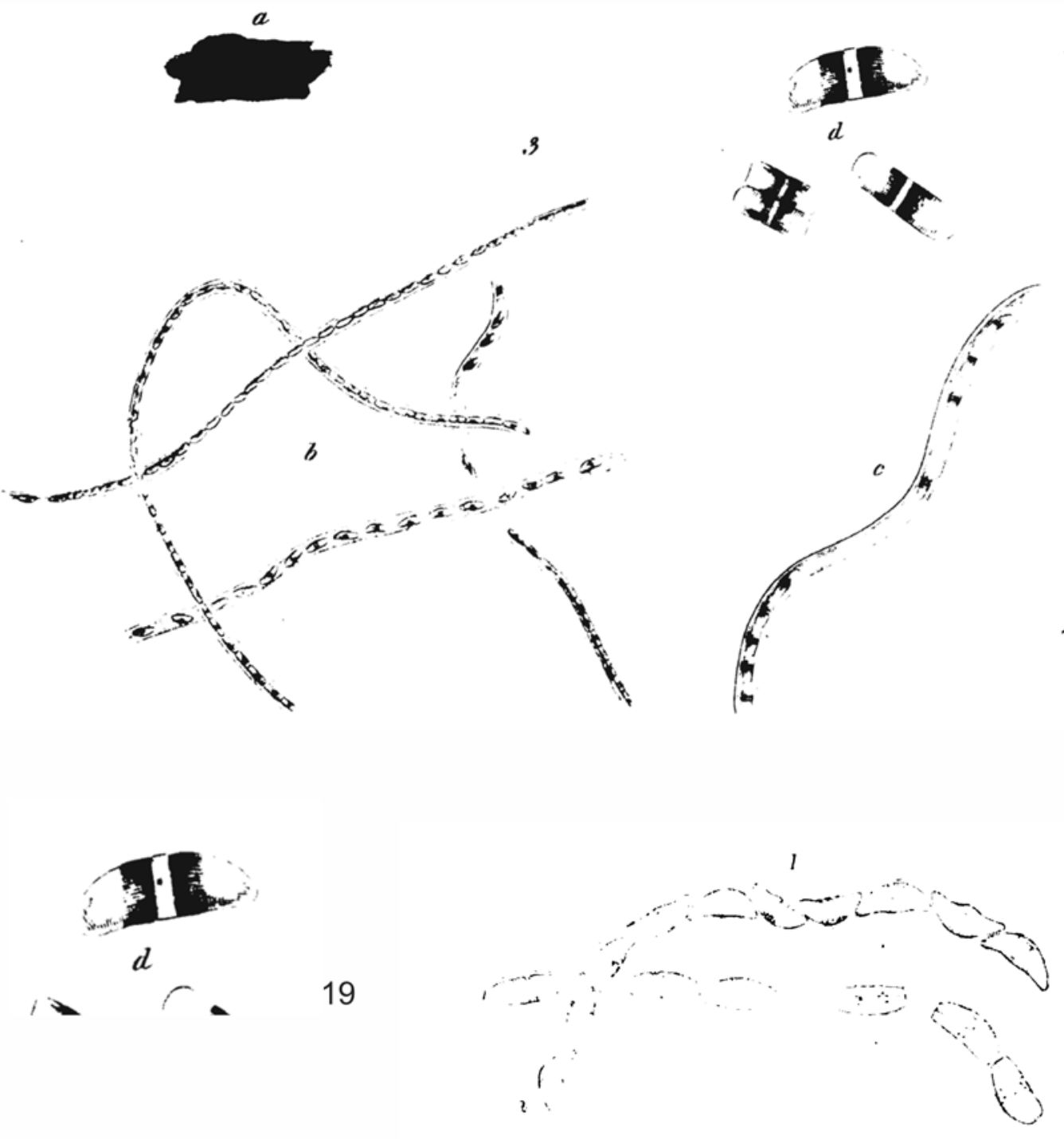

Figs 18-20. Monema prostratum Berk. provided by Berkeley (1832, tab. 4, fig. 3): (19) Part of “tab. 4, fig. 3" provided by Berkeley (1832), lectotype (here designated); (20) E. prostratum by KützING (1849), treated as Encyonema paradoxum Kürz. sensu Kützing (1844, taf. 22, fig. I).

dorsal margin strongly convex, ventral margin straight to slightly convex, sometimes showing an intumescence in the middle part of the ventral margin; rounded ends not protracted to slightly displaced to the ventral side; length: $15-37 \mu \mathrm{m}$, breadth: $8-12 \mu \mathrm{m}$, length/breadth ratio: 1.5-3.3; axial area straight and linear-lanceolate, central area indistinct to slightly rounded; raphe lateral, terminal ends deflected to the ventral side, proximal ends slightly deflected to the dorsal side, terminal nodules positioned on the ventral side, central nodule on the dorsal side; striae radiate on the dorsal and ventral sides, striae on the ventral margin of the same size, $9-12$ striae in $10 \mu \mathrm{m} ; 21-25$ puncta in $10 \mu \mathrm{m}$; stigmata absent.
Encyonema triangulum (EHRENB.) KüTZ., 1849, Sp. Alg.: 62. (Figs 46-48).

Basionym: Gloionema triangulum EHRENB., 1845, Ber. Bekanntm. Verh. Königl. Preuss. Akad. Wiss. Berlin 1845: 77.

Lectotype (here designated): One specimen in preparation no. 250608c "Niagara", marked with a lilac ring, Ehrenberg Collection, at the Museum für Naturkunde (BHUPM), Berlin (Fig. 48).

Type locality: Niagara, Canada.

Original description: "Gl. Corpusculis naviculaceis utrinque acutis, dorsi gibbere altiore inaequalibus et in formam a latere conspicuam triangularem abeuntibus. Diam. Naviculae 1/66",', 

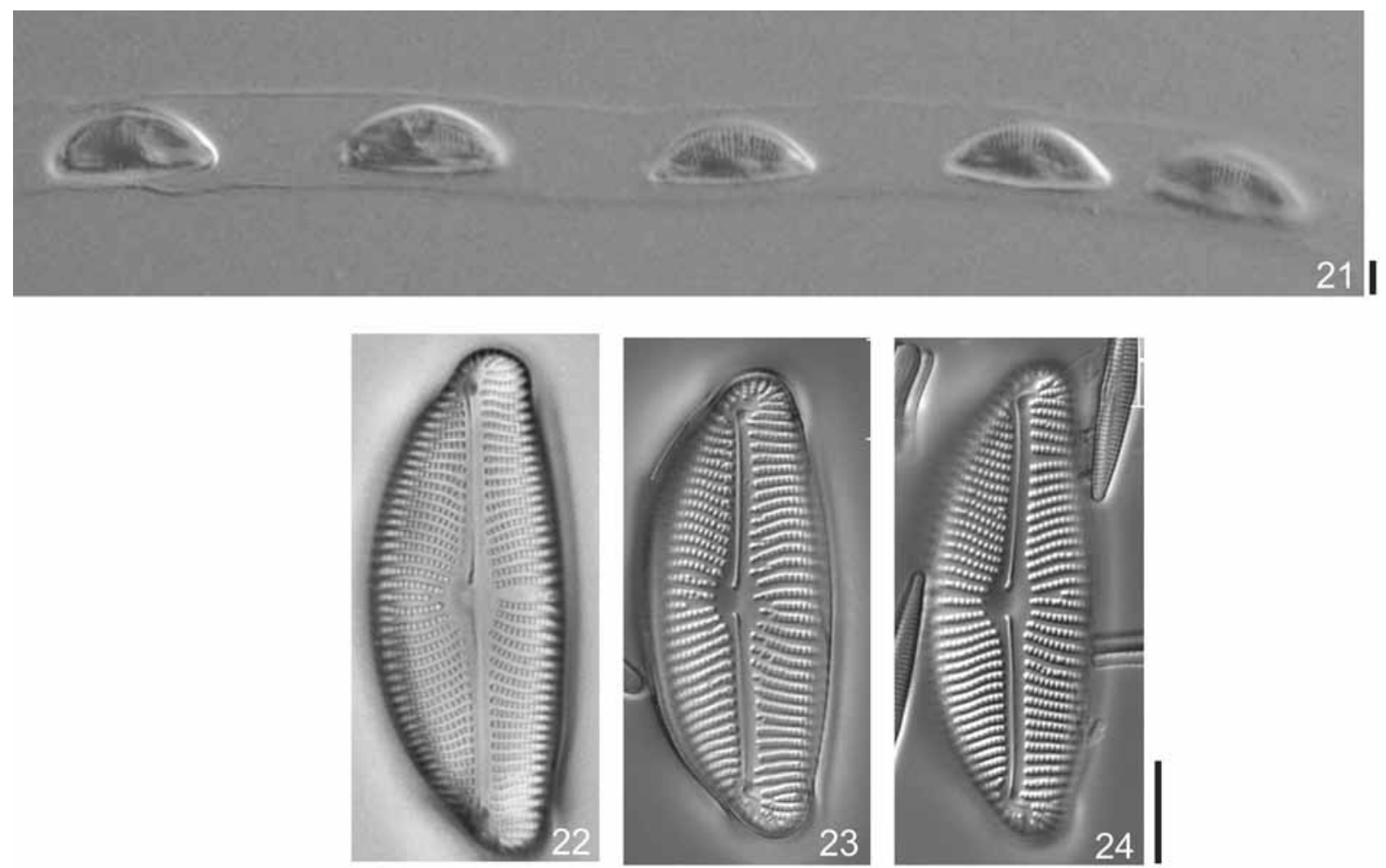

Figs 21-24. Encyonema prostratum (BerK.) KüTZ.: (21-22) Material from Tegel Lake, Berlin, (21) Live material showing colonial habit, with frustules in mucilaginous tubes, (22) E. prostratum in preparation B 400040926 from Tegel Lake, Berlin, epitype (here designated); (23-24) Material from E. cespitosum from Weissensee in Füssen, in preparation 321 IOK in BRM, Bremerhaven.

Remarks: Valvae dorsiventral, lanceolate, dorsal margin strongly convex, ventral margin convex; apiculate ends, slightly displaced to the ventral side; length: $31 \mu \mathrm{m}$, breadth: $15 \mu \mathrm{m}$, length/breadth ratio: 2; axial area linear-lanceolate, central area indistinct; raphe filiform, terminal ends deflected to the ventral side, proximal ends slightly deflected to the dorsal side, central nodule on the dorsal side; striae radiate on the dorsal side and parallel to radiate on the ventral side, 13 striae in $10 \mu \mathrm{m}$; 16 puncta in $10 \mu \mathrm{m}$; dorsal stigmoid. Synonym: $\equiv$ Cymbella triangulum (Ehrenb.) Cleve, 1894, K. Svenka Vet.-Akad. Handl., ser. 4, 26(6): 168.

Encyonema lacustre (C. AgARdh) PANT., 1901, Balat. Kovam.: 24. (Figs 49-59).

Basionym: Schizonema lacustre C. Agardh, 1824, Syst. Alg.: 10.

Lectotype (here designated): Marked specimen on slide 3673, in the Herbarium of the University of Lund, produced from oxidized material of exsiccate 3673 (LD) (Fig. 55).

Isolectotype: Marked specimen on slide R 214.004, in the Herbarium of the Museu Nacional (R), produced from oxidized material of exsiccate 3673 (LD).

Type locality: Sweden: Lake Mälaren, near Stockholm. Original description: "filis subramosis caespitosis acutis fuscescentibus, granulis confertis adpressis, membrana fili inconspicua".

Remarks: Valvae slightly dorsiventral, romboidal, the two margins convex; ends rounded, not protracted; length: $40-44 \mu \mathrm{m}$, breadth: $8-11 \mu \mathrm{m}$, length/breadth ratio: 3.95-4.72; axial area straight and linearlanceolate, central area indistinct to slightly rounded; raphe filiform, terminal ends deflected to the ventral side, proximal ends slightly deflected to the dorsal side, terminal nodules positioned on the ventral side, central nodule on the dorsal side; striae radiate on the dorsal and ventral sides, converging close to the ends of the valvae, $7-12$ striae in $10 \mu \mathrm{m} ; 20-27$ puncta in $10 \mu \mathrm{m}$; stigmata absent.

\section{Discussion}

According to the original description, Encyonema encompassed organisms with a mucilaginous tube that encloses a group of serially arranged cymbelloid cells (KüTZING 1833). These characteristics refer to the colonial habit; this habit can be assumed to be general in species of the genus, but has been reported only for $E$. paradoxum, E. prostratum, E. cespitosum, E. lacustre and $G$. leibleinii. Similar descriptions of diatoms based on the characteristics of the colony were very common up to the mid-19 ${ }^{\text {th }}$ century (e.g., AgardH 1824, 1827, 1830; Ehrenberg 1838; Greville 1827; KütZING 1833, 1844, 1849; Lyngbye 1819; Nitzsch 1817).

The use of colony morphology as a taxonomic 

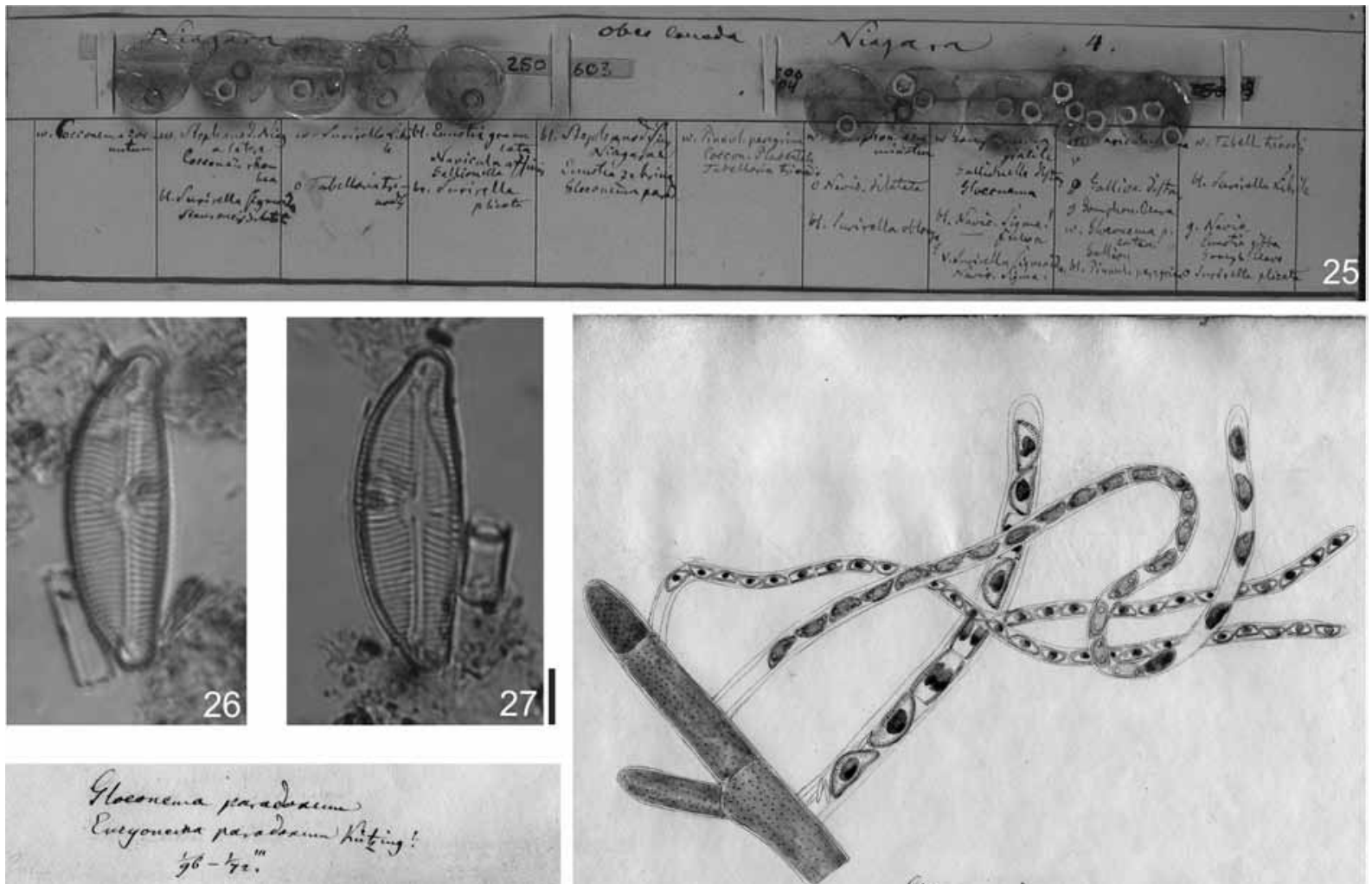

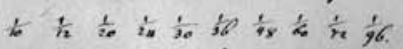


Figs 25-29. Material of Gloionema [Gloeonema] paradoxum C.AGARDH sensu EHRENBERG: (25) Micastrips No. 250603 and 250604 of material from Niagara, Canada, Ehrenberg Collection, in BHUPM, Berlin; (26-29) Gloionema [Gloeonema] paradoxum C.AGARDH sensu EHRENBERG, (26) Specimen found in preparation 250603e "Niagara", marked with a blue ring (bl), Ehrenberg Collection, in BHUPM, Berlin, (27) Specimen found in preparation 250604c "Niagara", marked with a white ring (w), Ehrenberg Collection, in BHUPM, Berlin, (28) Drawing sheet No. 677, (29) Part of drawing sheet No. 677 showing the measurements of different specimens (in Paris lines) made by EHRENBERG.

character in diatoms ceased in the later studies in the $19^{\text {th }}$ century, when the researchers concentrated their descriptions on the frustules, e.g. CLEve (1873), Van Heuck (1896), and Hustedt (1930). Indeed, such colonial characters are shared among species of different genera (e.g., Amphipleura Kürz., Navicula Bory and Parlibellus E.J. Cox), and therefore this feature is not a robust character to circumscribe taxa at generic level.

The characterization of E. paradoxum provided by KüTZING (1833) allows us to verify that this species belongs to the genus Encyonema as currently understood. However, it is not known if all species of Encyonema exhibit the tube-like colonial habit, or if it is due to particular environmental conditions.

It is undeniable that the instability of the type species of the genus Encyonema can also lead to instability in the genus. This is a consequence of the lack of a type specimen, and therefore the relationships among the type and other species of the genus will remain unclear. Despite this taxonomic instability, Encyonema has been applied to the dorsiventral diatoms, with the proximal ends of the raphe deflected to the dorsal side and the external terminal fissures bent to the ventral side (KRAMMER 1997a), even without knowing the type specimen of the genus. Nevertheless, the designation of types is fundamental to taxonomy because names are permanently attached to them, one of the principles that aims to ensure taxonomic stability (MCNeILL et al. 2012).

Despite being the type of the genus, $E$. paradoxum has been considered a synonym of Gloionema paradoxum, G. leibleinii and E. prostratum [三Cymbella prostrata (Berk.) Cleve] (Ehrenberg 1838, VanLandingham 1971). The lack of any specimen of the protologue, illustrations with few details, and a too-general description do not allow a separation between E. paradoxum and E. prostratum, and lead to disagreements about the conspecificity of these two species and G. leibleinii.

EHRENBERG (1838, p. 237), in materials from Germany, Sweden, Denmark and France, accepted Gloionema paradoxum, in which he included $E$. paradoxum and $G$. leibleinii as synonyms. The 


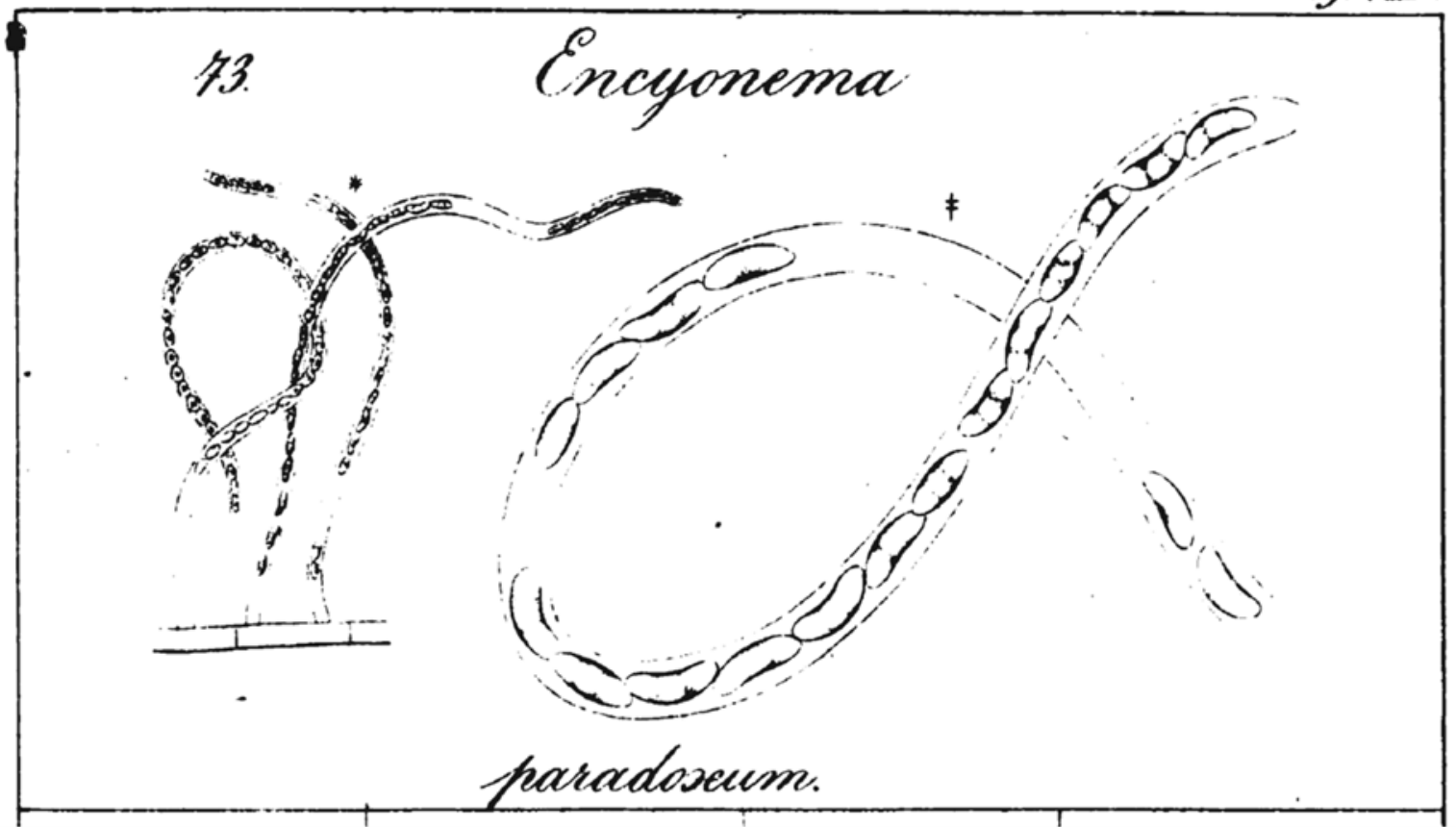

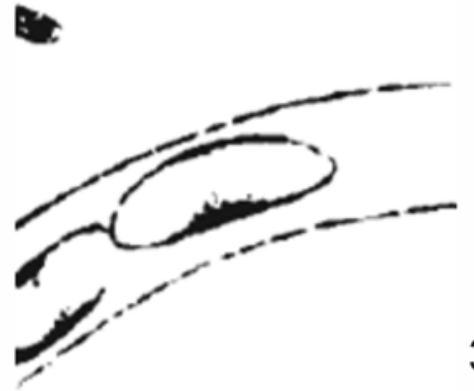

31
Figs 30-31. Encyonema paradoxum KüTZ. provided by KüTZING (1833, plate VII, fig. 73): (30) Part of taf. VII; (31) provided by KüTZING (1833), lectotype (here designated).

(Ag. 3299 LD) also proved to be different from $G$. paradoxum, but is conspecific with G. paradoxum sensu EHRENBERg (1838) and concords with the current concept of E. prostratum.

Additional information about E. paradoxum and E. prostratum provided by KüTZING $(1844 ; 1849)$ and RABEnHorst (1853) generated more confused concepts. KüTZING (1844), for example, confused the concepts of E. paradoxum with E. prostratum, and of E. prostratum with the concept that was later described as E. cespitosum (KÜTZING 1849).

KüTZING (1849) stated that E. paradoxum has one intumescence in the middle part of the ventral margin and has a length equal to $1 / 100$ "'. Such an intumescence can be observed neither in the original illustrations (Figs 1,2) nor in the first description [i.e., KÜTZING (1833)]. In the studies of KüTZING (1849), each Paris line corresponds to $2.265 \mathrm{~mm}$ (SIMONSEN 1975). Small but different correspondence values can be found in the studies of Christian Gottfried Ehrenberg, where according to J JHN (1995), each Paris line corresponds to $2.256 \mathrm{~mm}$. This value has also been adopted by other

The lectotype here designated for $G$. leibleinii 

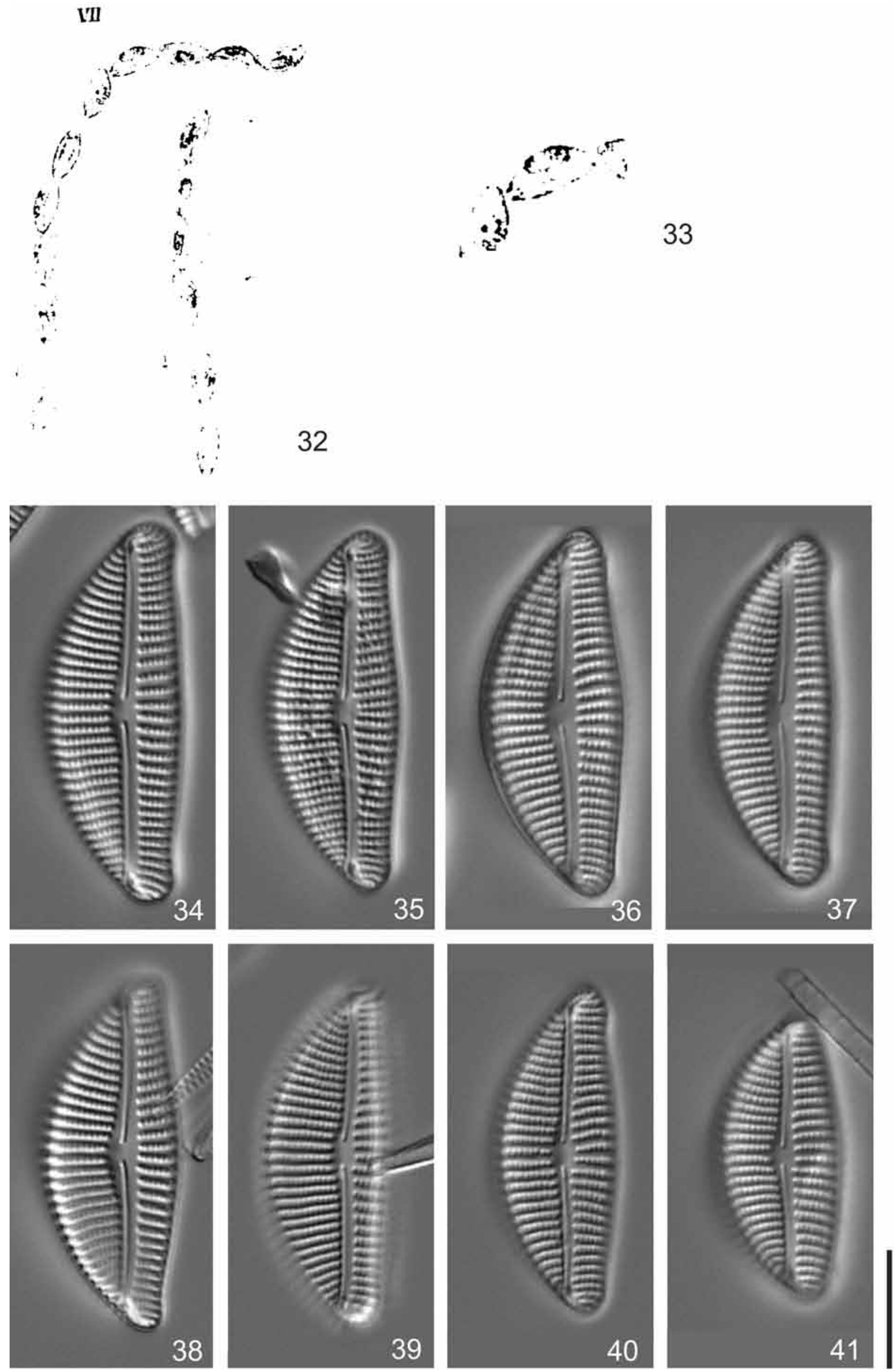
authors [e.g., Schoeman \& Archibald (1976)]. Thus, probably, the value provided by SiMONSEN (1975) could have been a lapse or a typographic error. Therefore, the only value of length provided by KüTZING (1849) for E. paradoxum would correspond to either $22.56 \mu \mathrm{m}$ or $22.65 \mu \mathrm{m}$.

The apparently consistent characteristics provided by KüTZING (1849) to distinguish the two taxa were the ventral intumescence in E. prostratum; the length, which is greater in E. prostratum $(22.65 \mu \mathrm{m}$ versus $45.3 \mu \mathrm{m}$ ); and the breadth of the mucilaginous tube, which is broader in E. paradoxum $(113.25 \mu \mathrm{m}$ versus $37.75-41.18 \mu \mathrm{m})$. Nevertheless, we are not sure if these features were defined based on the original material, or, again, if these are mistaken concepts. Therefore, we continue to consider only the original material as a basis to agree with the synoymization of G. leibleinii, E. paradoxum and E. prostratum.

Krammer (1997b) analyzed distinct concepts used by different authors during the history of $E$. prostratum, and described its length as ranging from 38 to $94 \mu \mathrm{m}$ and its breath from 16 to $25 \mu \mathrm{m}$; he also recorded specimens with a slight intumescence. However, these metric values presented by KRAMMER (1997b) are somewhat discrepant. If we consider the maximum length of $94 \mu \mathrm{m}$ described by the author and divide it by any value of breadth $(16-25 \mu \mathrm{m})$, we obtain length/breadth ratios between 3.76 and 5.88. Therefore, any value of this range will be higher than the maximum value of the length/breadth ratio provided by KRAMMER (1997b). We may consider that some of his metric data (i.e., maximum length, maximum breadth, or maximum length/breath ratio) were misleading, and that the higher maximum length/ breadth ratio that we found for the material from Tegel Lake is the true value for the epitype of E. prostratum.

We reanalyzed preparation $321 \mathrm{IOK}$, which was used by KRAMmer (1997b), and found values for length ranging from 37 to $88 \mu \mathrm{m}$, breadth from 16 to 24.7 $\mu \mathrm{m}$, and length/breath ratio from 1.94 to 4.4 . These values agree partially with the values provided by KRAMMER (1997b), except for the maximum length and the maximum length/breadth ratio. This material also agrees with the first description and with the original illustration (Fig. 4), chosen here as the lectotype of the species. This material was also similar to Monema prostratum, E. prostratum sensu KüTZING (1849), G. leibleinii, and G. paradoxum sensu EHRENBERG (1838).

Thereby, if we consider that E. paradoxum, published in 1833 , M. prostratum, in 1832 , and

Figs 32-41. Encyonema cespitosum KüTz.: $(32,33)$ E. prostratum sensu KüTZING (1844, taf. 25, fig. VII), cited in the protologue of E. cespitosum by KüTZING (1849), (33) Part of the drawing of $E$. prostratum, here designated as the lectotype of E. cespitosum; (34-41) E. cespitosum from Weissensee in Füssen, in preparation $321 \mathrm{IOK}$ in BRM, Bremerhaven.
G. leibleinii, in 1830, are synonymous, the epithet leibleinii has priority. Since G. leibleinii was not combined in the genus Encyonema, a new combination is required. E. paradoxum becomes the synonym of $G$. leibleinii. Similar cases have occurred in other genera, such as Aulacoseira THWAITES, where the type species became a synonym of another species of the genus (Crawford et al. 2003).

Further with respect to the identity of $E$. paradoxum in relation to E. prostratum, HustedT (1930) raised doubts about the independence of E. cespitosum and E. auerswaldii in relation to $E$. prostratum. PATRICK \& ReIMER (1975), agreeing in part with the considerations of HustedT (1930), treated $E$. auerswaldii as a variety of Cymbella prostrata (BERK.) CLEVE (EE. prostratum), creating the new combination Cymbella prostrata var. auerswaldii ReIMER. They treated part of E. cespitosum as a synonym of this new variety. Based on different characters of the isolectotype of E. auerswaldii, KRAMMER (1997a) considered this taxon to be reestablished at the species level. We observed, based on the epitypes, that the specimens of E. prostratum are broader than E. cespitosum (16-24.7 $\mu \mathrm{m}$ versus 9.6-12 $\mu \mathrm{m})$. The length of E. prostratum can reach $88 \mu \mathrm{m}$, whereas E. cespitosum has a maximum of $47 \mu \mathrm{m}$. Krammer (1997a, b) described maximum lengths of 94 and 45.6 $\mu \mathrm{m}$ for the two species, respectively.

KRAMMER (1997a) also designated a neotype of $E$. cespitosum. Although this "neotype" accords with the description provided by KüTZING (1849) and the drawings on which he based his description, this designation is not valid according to ICN Article 9.7 because there still exists original material that can be designated as a lectotype (MCNeILL et al. 2012). We, however, declare the material used by KrAmMER (1997a) as an epitype, after designating an illustration of $E$. cespitosum in KütZING (1844, taf. 25, fig. VII), as indicated by KüTZING (1849) in the protolog, as the lectotype of the species.

KRAMMER (1997a) described two varieties for $E$. cespitosum: E. cespitosum var. comensis KRAMMER and E. cespitosum var. maximum KrAmmer, erroneously using the epithet maxima. He used characters such as the outline and the shape of the ends, as well as metric characters to distinguish the two new varieties of the nominate variety. However, in examining the phenotypic variation of the populations, we observed an overlap in these characteristics (Figs 10-26). Thus, we consider that the differences highlighted by KRAMMER (1997a) are insufficient to distinguish the two varieties in relation to the lectotype of E. cespitosum, and we therefore treat the two varieties as synonyms of the nominate variety. 

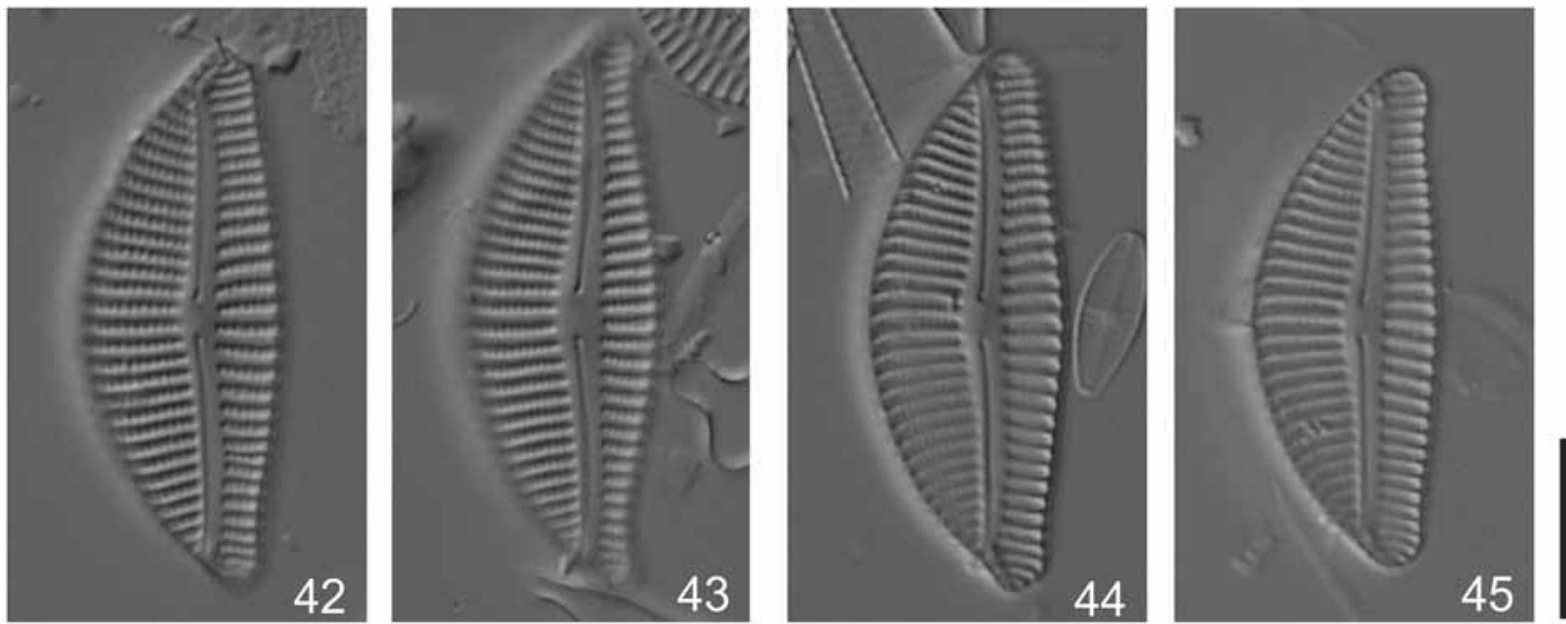

Figs 42-45. Encyonema auerswaldii RABENH. from Leipzig in preparation 1126 IOK at the Alfred-Wegener-Institut für Polar- und Meeresforschung (BRM), Bremerhaven.

\section{Conclusion}

Inspection of the original material of E. paradoxum, E. prostratum, E. cespitosum, E. auerswaldii, E. triangulum, E. lacustre and Gloionema leibleinii showed that the characters of these species agree with the current concept of Encyonema.

E. prostratum is very similar to G. leibleinii, and is therefore considered by us as a synonym. Since G. leibleinii was published before M. prostratum, the epithet leibleinii has priority over the latter name. However, the epithet leibleinii is not currently combined in the genus Encyonema, and we therefore propose a new combination.

In the future, studies of the colonial habit of other species of the genus Encyonema should be carried out in order to determine if this capability is exclusive to a group of species in this genus or if it is related to environmental conditions. Such characteristics could indicate the possibility of the existence of internal groups in Encyonema, or provide important information about the evolution of the group.

\section{REFERENCES}

Agardh, C.A. (1812): Dispositio Algarum Suecia. - Litteris Berlingianus, Lundae [Lund], 5: 1-45.

Agardh, C.A. (1824): Systema algarum.- 312 pp., Litteris Berlingianus, Lundae [Lund].

Agardh, C.A. (1827): Aufzählung einiger in den österreichischen Ländern gefundenen neuen Gattungen und Arten von Algen nebst ihrer Diagnostik und beigefügten Bemerkungen. - Flora oder Botanische Zeitung, 40: 625-646.

Agardh, C.A. (1830): Conspectus criticus diatomacearum. Literis Berlingianus, Lundae [Lund], 1: 1-16.

Berkeley, M.J. (1832): Gleanings of British algae. -32 pp.,
C.E. Sowerby, London.

Cleve, P.T. (1873). On diatoms from the Arctic Sea. - Kongliga Svenska Vetenskaps-Akademiens Handlingar 1: 1-28.

Crawford, R.M.; Likhoshway, Y.V. \& JAhN, R. (2003). Morphology and identity of Aulacoseira italica and typification of Aulacoseira (Bacillariophyta). Diatom Research 18: 1-19.

EhrenBerG, C.G. (1838): Die Infusionsthierchen als vollkommene Organismen. Ein Blick in das tiefere organische Leben der Natur. - 555 pp., Verlag von Leopold Voss, Leipzig.

GrevilLe, R.K. (1827): Scottish cryptogamic flora. MacLachlan \& Stewart; Baldwin, Craddock \& Joy. 5: 49-54.

Heiberg, P.A.C. (1863): Conspectus criticus diatomacearum danicarum. - 135 pp., Wilhelm Priors Forlag, København.

Hustedt, F. (1930): Die Kieselalgen Deutschlands, Österreichs und der Schweiz unter Berücksichtigung der übrigen Länder Europas sowie der angrenzenden Meeresgebiete. - Kryptogamen Flora von Deutschland, Österreich und der Schweiz 7: 609920.

JAHN, R. \& KUSBER, W.-H. (2006): Algae of the Ehrenberg collection -3 . Typification of seven diatom taxa described by C. G. Ehrenberg predominantly from Greece. - Willdenowia 36: 527-535.

JAHN, R. (1995): C.G. Ehrenberg's concept of the diatoms. Archive für Protistenkunde 146: 109-116.

Krammer, K. (1997a): Die cymbelloiden Diatomeen, eine Monographie der welweit bekannten Taxa. Teil 1. Allgemeines und Encyonema Part. - Bibliotheca Diatomologica 36: 1-382.

Krammer, K. (1997b): Die cymbelloiden Diatomeen, eine Monographie der welweit bekannten Taxa. Teil 2. Encyonema Part., Encyonopsis and Cymbellopsis. Bibliotheca Diatomologica 37: 1-469.

KützING, F.T. (1833): Synopsis Diatomacearum oder Versuch einer systematischen Zusammenstellung der Diatomeen. - Linnaea 8: 529-620.

KÜTZING, F.T. (1844): Die kieselschaligen Bacillarien oder Diatomeen. - 152 pp., Nordhausen. 

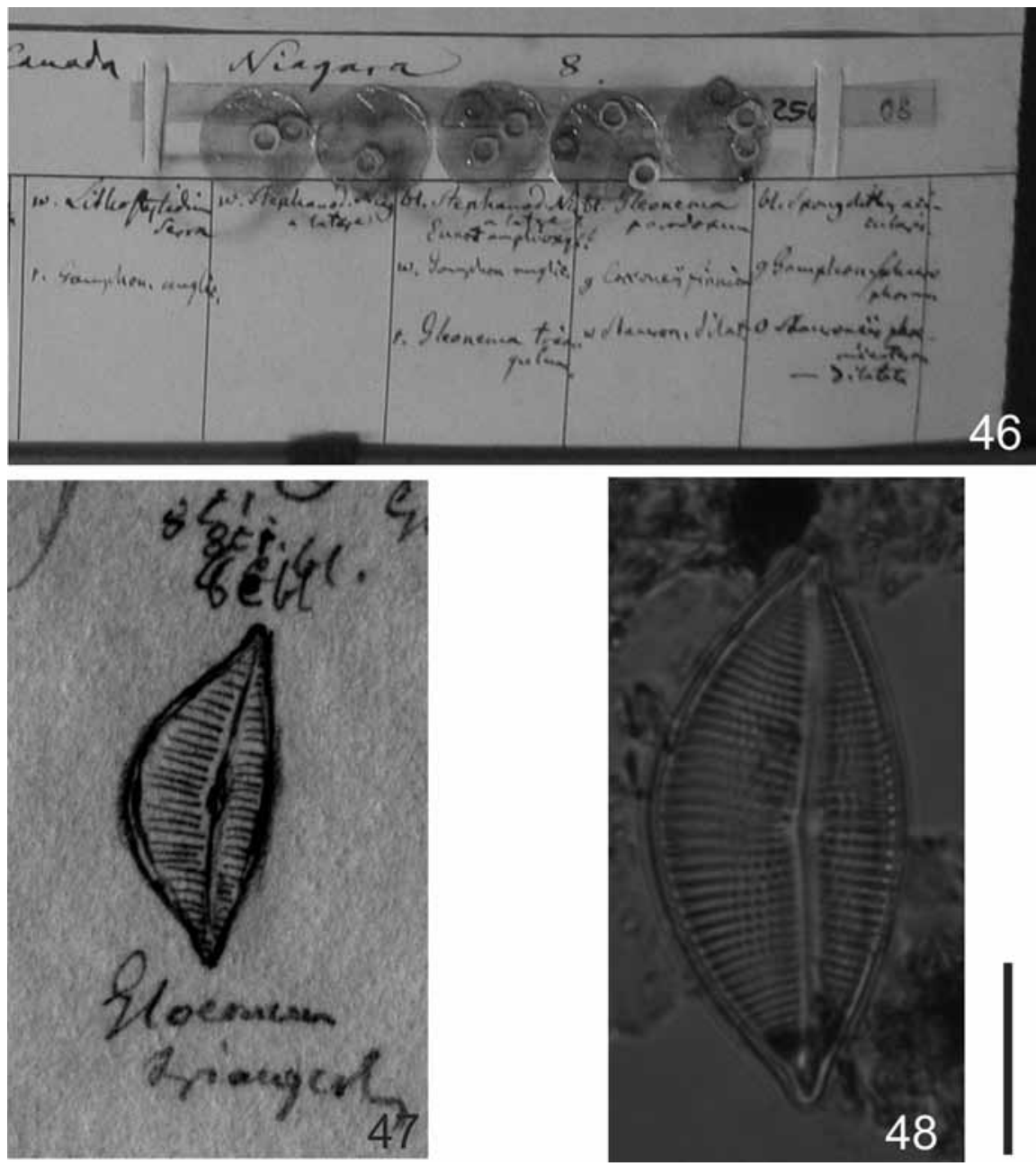

Figs 46-48. Original material of Gloionema [Gloeonema] triangulum EHRENB.: (46) Micastrip No. 250608 of material from Niagara, Canada, Ehrenberg Collection, in BHUPM, Berlin; (47-48) Gloionema [Gloeonema] triangulum EHRenB., (47) Part of the drawing sheet No. 2079 from Niagara, (48) Lectotype of $G$. triangulum in preparation no. $250608 \mathrm{c}$ "Niagara", marked with a lilac ring, Ehrenberg Collection, in BHUPM, Berlin.

Kützing, F.T. (1849). Species Algarum. - 922 pp., F.A. Brockhaus, Lipsiae [Leipizig].

Lapage, S.P.; Sneath, P.H.A.; Lessel, E.F.; Skerman, V.B.D.; SeEliger, H.P.R. \& Clark W.A. (1992): International Code of Nomenclature of Bacteria: Bacteriological Code, 1990 Revision [online].-ASM Press, Washington (DC). Available from: http://www.ncbi. nlm.nih.gov/books/NBK8817/ [Accessed 22 January 2012].

LAzARus, D. \& JAHN, R. (1998). Using the Ehrenberg Collection. - Diatom Research 13: 273-291.

LyNGBYE, H.C. (1819): Tentamen hydrophytologiae danicae continens omnia hydrophyta cryptogama Danica. - 280 pp., Librariae Gyldendaliae, Hafniae [Copenhagen].

McNeill, J.; Barrie, F.R.; Buck, W.R.; Demoulin, V.; Greuter, W.; Hawksworth, D.L.; HerendeEn, P.S.; Knapp, S.; Marhold, K.; Prado, J.; Prud'Homme Van Reine, W.F.; SMith, G.F.; Wiersema, J.H. \& TuRland N.J. (2012). International Code of Nomenclature for algae, fungi, and plants (Melbourne Code) adopted by the Eighteenth International Botanical Congress Melbourne, Australia, July 2011. - Regnum Vegetabile: 154: 1-240.

Nitzsch, C.L. (1817). Beitrag zur Infusorienkunde oder Naturbeschreibung der Zerkarien und Bazillarien. Neue Schriften der Naturforschenden Gesellschaft zu Halle 3: 1-128.
Patrick, R. \& Reimer, C.W. (1975): The diatoms of the United States. Exclusive of Alaska and Hawaii. Vol. 2, Part 1. - Monographs of the Academy of Natural Sciences of Philadelphia 13: 1-213.

RABENHORST, L. (1853): Die Süsswasser-Diatomaceen (Bacillarien.): für Freunde der Mikroskopie. -84 pp., Eduard Kummer, Leipzig.

Ride, W.D.L.; Cogger, H.G.; Dupuis, C.; Kraus, O.; Minelli, A.; Thompson, F.C. \& Tubbs P.K. (1999): International Code of Zoological Nomenclature [online]. 4a. -The International Trust for Zoological Nomenclature, London. Available from: http://www. nhm.ac.uk/hosted-sites/iczn/code/ [Accessed 22 January 2012].

Schoeman, F.R. \& Archibald, R.E.M. (1976): The diatom flora of Southern Africa. - Council for Scientific and Industrial Research, Pretoria.

Simonsen, R. (1975): The diatoms Navicula pygmaea Kützing and N. hudsonis Grunow. - British Phycological Journal 10: 169-178.

Van Heurck, H. (1885): Synopsis des Diatomées de Belgique. -235 pp., Martin Brouwers \& Co., Anvers.

VAN Heurck, H. (1896): A treatise on the Diatomaceae.-558 pp., William Wesley \& Son, London.

Van Landingham, S.L. (1971). Catalogue of the fossil and recentgenera and species of diatoms and their synonyms. Part 4.Fragilaria through Naunema. 629 pp., J. Cramer, Lehre. 

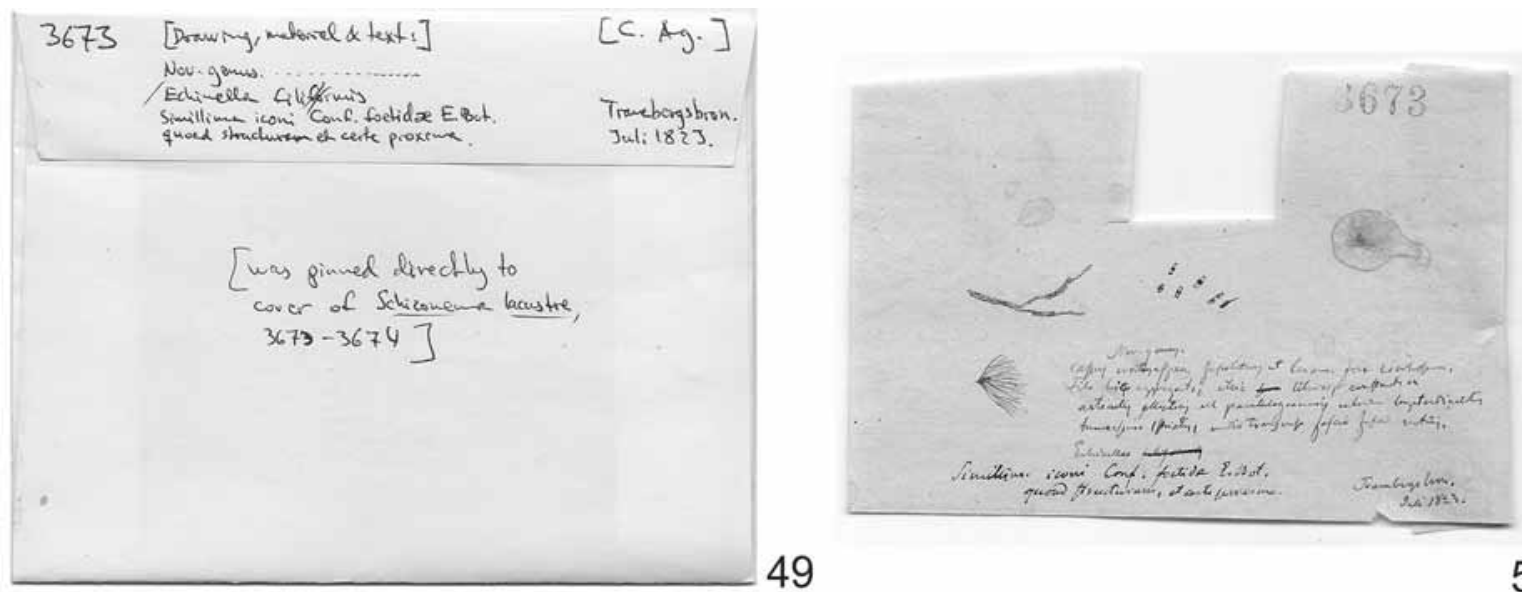

49

50
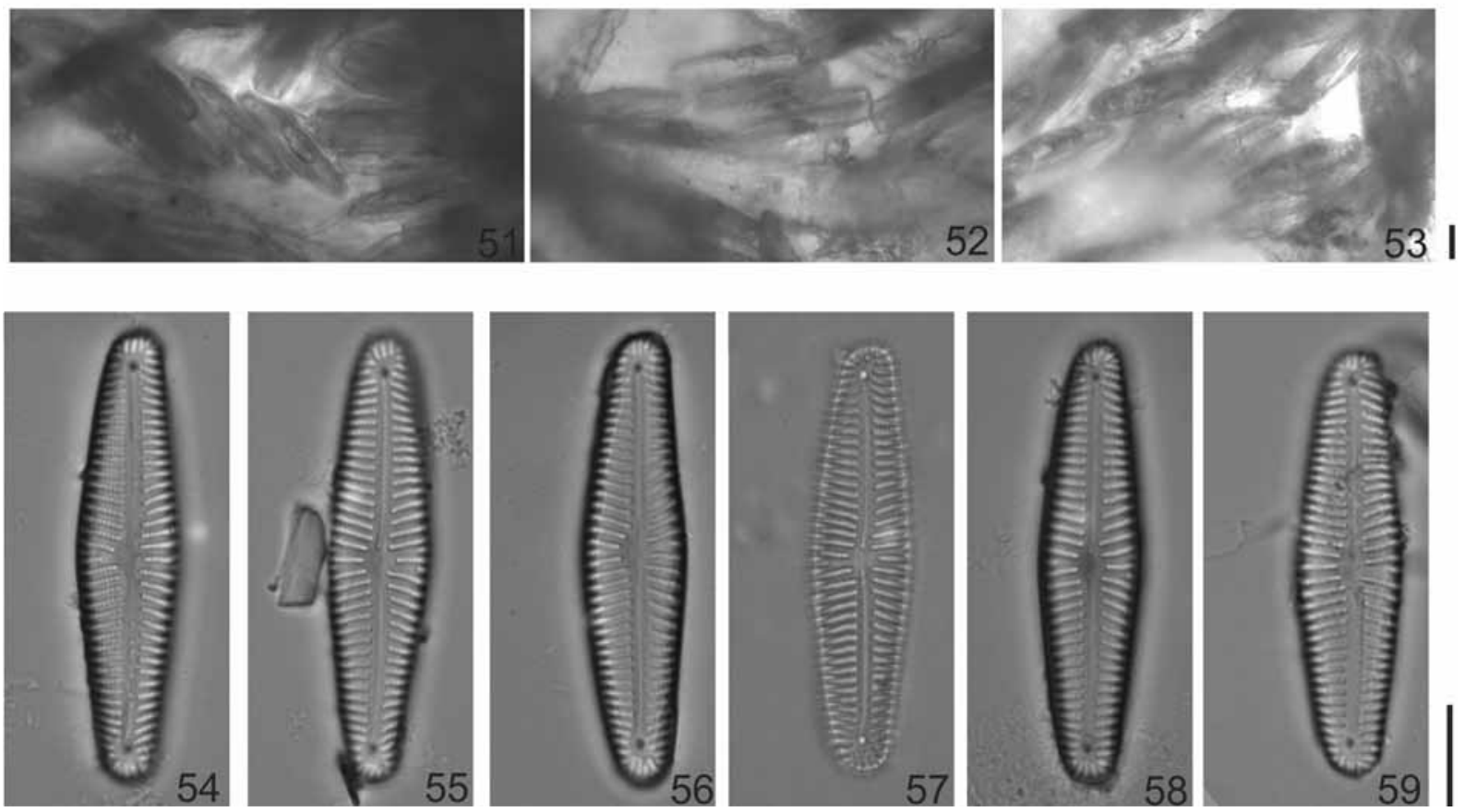

Figs 49-59. Type material of Encyonema lacustre (C. Agardh) PAnt. [Schizonema lacustre C.Agardh]: $(49,50)$ Exsiccate LD 3673 of S. lacustre; (51-53) Specimens of S. lacustre on the paper of the exsiccate; (54-59) Oxidized specimens of S. lacustre; (55) Lectotype (designated here) of S. lacustre on slide LD 3673, in LD, Sweden.

(C) Czech Phycological Society (2013)

Received April 1, 2013

Accepted May 22, 2013 